ISSN: 2162-3104 Print/ ISSN: 2166-3750 Online

Volume 7, Number 3, July/August (2017) pp. I-IX

(C) Journal of International Students

http://jistudents.org/

\title{
Rethinking the Politics of the International Student Experience in the Age of Trump
}

\author{
CindyAnn Rose-Redwood \\ University of Victoria, Canada \\ Reuben Rose-Redwood \\ University of Victoria, Canada
}

$\mathbf{W e}$ are living in troubling and uncertain times. Xenophobia is on the rise as right-wing, authoritarian nationalism has witnessed significant electoral gains and the very ideals of democratic inclusiveness and international pluralism are under direct attack. With the election of Donald Trump as President of the United States, the country with the largest share of international students globally is increasingly becoming an unwelcoming place to study abroad. On January 27, 2017, Trump issued an executive order prohibiting entry of citizens from seven Muslim-majority countries (Iran, Iraq, Libya, Somalia, Sudan, Syria, and Yemen), and severely restricting the admission of refugees, into the United States. This initial attempt at a "Muslim travel ban" was subsequently blocked by the federal courts, yet the ongoing efforts of the current U.S. administration to discriminate against Muslim travelers at the border have had a chilling effect on international travel more generally.

Trump signed a new executive order on March 6, 2017, reinstating the travel ban with some modifications (e.g., Iraq is no longer included on the list of banned countries). This second attempt at a Muslim travel ban has also been blocked by the courts, and while it is too early to tell what its long-term consequences will be for international students in the years ahead, the travel ban has already resulted in a significant decline in international tourists entering the U.S. and may have a "real and lasting impact on the tourism economy" (Baran, 2017). International concerns over the anti- 
Muslim and anti-immigrant policies of the Trump administration were powerfully encapsulated in the front cover image of the German news magazine, Der Spiegel, depicting Trump with a bloody knife in hand after having beheaded the Statue of Liberty, which has long been a symbol of America as a welcoming place for immigrants and refugees (Brinkbäumer, 2017).

This is a critical time for scholars who study international students to re-assess our research agenda for the field, because we simply cannot proceed as if it were business as usual within the current political context. Not only are international students experiencing a "world in flux" (Glass, 2017), the international student community is currently living in a precarious world of insecurity in which international students are increasingly becoming the targets of violence and discrimination based on race, religion, ethnicity, and national origin. In this editorial, we consider how the Muslim travel ban in the U.S. has affected international students and scholars, how higher education institutions have responded to this threat to their core values, and how scholarship on international students can reorient its focus by highlighting the political dimensions of the international student experience.

\section{Not Welcome Here: Discriminatory Immigration Policy and its Implications for International Students in the United States}

During the 2015-2016 academic year, there were 1,043,839 international students studying at higher education institutions in the United States, which

$\begin{array}{ll}\text { Countries of Origin } \quad \text { Numbers of Students } & \begin{array}{l}\% \text { of Total International } \\ \text { Students in the U.S. }\end{array}\end{array}$

\begin{tabular}{lcc}
\hline Iran & 12,269 & 1.18 \\
Iraq & 1,901 & 0.18 \\
Libya & 1,514 & 0.15 \\
Syria & 783 & 0.08 \\
Yemen & 599 & 0.06 \\
Sudan & 253 & 0.02 \\
Somalia & 35 & 0.003 \\
TOTAL & 17,354 & 1.7 \\
\hline
\end{tabular}

International students directly affected by the initial U.S. travel ban (Institute of International Education, 2016) 
constituted approximately 5.2 percent of total student enrollments nationwide (Institute of International Education, 2016). This represents an all-time high in international student enrollments with China and India accounting for the largest share of international students studying in the U.S. (31.5 percent and 15.9 percent, respectively). Of this total, 1.7 percent of international students at colleges and universities in the U.S. were from one of the seven countries directly affected by the initial travel ban.

Of the directly-impacted countries, only Iran was among the top 25 places of origin for international students in the United States with over 12,000 Iranian students enrolled across the country. Yet measuring the impact of the travel ban in terms of enrollment figures alone is insufficient. The emotional stress, fear, and uncertainty that many international students are currently experiencing is simply beyond measure. International students and scholars-particularly those of the Muslim faith-who are already residing in the United States are concerned that if they leave the country to attend a conference or visit family, they may not be permitted to re-enter the U.S. to complete their studies (Chronicle of Higher Education, 2017). This concern is not unfounded, because as the initial travel ban went into effect, it "stranded students and scholars overseas and forced others on campuses in the United States to cancel research projects and other personal and professional travel out of the country for fear of not being allowed to return" (Blumenstyk, Najmabadi, \& Brown, 2017). Many international students feel "trapped" inside the U.S. and some are even considering withdrawing from their degree programs and leaving the U.S. altogether, because they do not want to spend long continuous periods of time away from their families without the possibility of travelling home periodically (Chronicle of Higher Education, 2017).

Despite the fact that the original Muslim ban was blocked by the courts, U.S. border agents continue to engage in discriminatory practices against Muslims from countries not even listed in the travel ban, including the UK and Canada (CBC, 2017; Morris, 2017). Even more troubling, Muslims with U.S. citizenship have also been detained and questioned about their religious beliefs when re-entering their own country (GrahamHarrison, 2017), all of which suggests that religious discrimination has now become the norm at the U.S. border.

Following the announcement of the Muslim travel ban, universities and scholarly associations strongly condemned the executive order and many demanded that it be immediately rescinded. Higher education institutions in the United States have long been committed to international cooperation and cross-cultural engagement in the pursuit of knowledge, and the travel ban had the effect of undermining this core mission of higher education. In response to the executive order, university leaders called 
attention to the impacts that it was having on international students, faculty, and other researchers, and these impacts on the university community played a significant role in the federal court ruling that halted the initial travel ban (Blumenstyk, 2017). As the Trump administration continues to pursue a discriminatory immigration policy that negatively affects international students and scholars, the university community will most certainly be at the forefront of legal cases to block such executive actions in the future as well.

\section{Towards a New Research Agenda on the Political Dimensions of the International Student Experience}

As the political landscape of higher education changes, it is crucial that educational scholars examine the politics of the international student experience. Much of the existing literature on international students has emphasized psychological and sociological themes, such as culture shock, homesickness, cultural adjustment, sense of belonging, and ethnic segregation. By comparison, relatively few studies have examined the international student experience from an explicitly political perspective (yet, see Ewers and Lewis, 2008; Madge, Raghuram, and Noxolo, 2009; Urias and Yeakey, 2009; Dunn, Pelleri, and Maeder-Han, 2011; Robertson, 2011; Paltridge, Mayson, and Schapper, 2014; Walker, 2014; Li, 2016).

Here we propose five key thematic areas that may serve as the basis of a new research agenda for scholarship on the political dimensions of the international student experience.

1. The Policy Environment. A variety of government policies have a direct bearing on international students. In particular, national immigration policies affect which students may enter a country to pursue higher education and regulate whether students can stay or must leave following the completion of their studies. Shifts in the policy environment are indicative of broader changes to the political landscape within which international students pursue their studies.

Key research questions to consider include:

o What implications do government policies have for the international student community?

o How do macro-level policies shape the everyday lives of international students?

o What role does the university play in monitoring international students as part of the enforcement of government immigration policies? 
o How have both international students and university officials responded to government policies that negatively affect the international student community?

2. The Socio-Political Atmosphere. The social and political context in which international students live, work, and study constitutes the "socio-political atmosphere" of the international student experience. By this, we refer to how the host community perceives and interacts with international students, whether international students feel welcomed or threatened by the host community, and the extent to which the political ambience of a society is hostile to immigrants more generally.

Key research questions to consider include:

o How are international students perceived by the host community?

o Has the host community created a welcoming or hostile environment for international students, and how do international students perceive their encounters with host national students, faculty, staff, administrators, and community members?

o In what ways, if any, have international students been framed as the "Other" in popular discourse and everyday practices?

o What steps, if any, have been taken to foster meaningful cross-cultural engagement between international students and the host community as a means of defusing a hostile or threatening atmosphere?

3. The Continuum of Violence and Discrimination. In contexts where xenophobia, racism, and religious hatred are prevalent, international students and other immigrants have been the targets of physical and symbolic violence as well as implicit and explicit discrimination. These acts fall along a continuum, ranging from everyday forms of microaggression to violent hate crimes. When the socio-political atmosphere is charged with tension, then violence and discrimination may become increasingly normalized, especially when xenophobic political views are espoused and legitimized by government policy.

Key research questions to consider include:

o How common are acts of violence and discrimination against international students and are students of specific 
nationalities, ethnicities, or religious affiliations being targeted?

o How have international students been directly impacted by discrimination based on race, gender, sexual orientation, ethnicity, nationality, or religion, and how has this affected their social and academic experience studying abroad?

o How have university officials, the police, the media, and the host community more generally responded to violent attacks and discriminatory acts against international students?

o What support networks do international students have when confronted with violence and discrimination?

4. The Degree of Student Activism and Resistance. Although international students are often portrayed as the passive victims of violence and discrimination, they also have the capacity to act politically by engaging in various forms of student activism and resistance. This may take the form of lobbying against government policies, challenging prevailing xenophobic ideologies and everyday racisms, or organizing support networks for those impacted by violence and discrimination.

Key research questions to consider include:

o What forms of political activism, if any, have international students participated in as part of their time studying abroad?

o What leads some international students to engage in activism while others do not?

o Do the political norms of an international student's home country influence whether they will act politically while studying abroad?

o How do international students negotiate and resist everyday forms of discrimination and "othering"?

5. The Researcher Positionality Effect. The social positionality of the researcher can have a significant effect on studies of the international student experience. In particular, whether the international students participating in a study consider the researcher to be an "insider" or "outsider" will likely affect the level of trust between the researcher and participants. Similarly, if a researcher is an international student or scholar, their "outsider" status with the host community may likewise affect what host nationals are willing to admit about their political views concerning non-citizens in interviews, focus groups, or surveys. This does not necessarily mean 
that only "insiders" can effectively conduct research on international students or the host community, but it does suggest that research results may vary depending on the researcher's positionality.

Key research questions to consider include:

o Is the researcher considered an "insider" or "outsider" by international students and host nationals, and how has the researcher taken their own social, cultural, and political positionality into account?

o How has the researcher framed their own subject position, as a neutral observer committed to scientific objectivity or as a co-producer of situated knowledges?

o How have the researcher's own assumptions about social, cultural, and political norms influenced their interpretation of social life among international students?

o In a politically-charged atmosphere, how has research on international students been used for different political ends, and how does the researcher's positionality affect the perceived legitimacy and use of their research findings?

By positing these questions, we hope to stimulate deeper reflection and critical analysis of the political aspects of the international student experience. Such political inquiry has the potential to contribute important insights that are of immediate relevance to policymakers, higher education institutions, and the international student community. As the policy environment, and socio-political atmosphere, in destination countries becomes increasingly hostile to international students, it is critical to reexamine the experiences of international students from a political vantage point.

\section{REFERENCES}

Baran, M. (2017). Data suggests a "Trump slump" in travel to U.S. Travel Weekly. Retrieved from http://www.travelweekly.com/North-America-Travel/Datasuggests-Trump-slump-in-travel-to-US

Blumenstyk, G. (2017). Universities spoke up in case that led to ruling halting Trump's travel ban. Chronicle of Higher Education. Retrieved from http://www.chronicle.com/article/Universities-Spoke-Up-in-Case/239128

Blumenstyk, G., Najmabadi, S., \& Brown, S. (2017). Court rebukes Trump's travel ban, and harm to universities plays a key role. Chronicle of Higher Education. Retrieved from http://www.chronicle.com/article/Court-RebukesTrump-s-Travel/239173 
Brinkbäumer, K. (2017). Trump's America: democracy at the tipping point. Der Spiegel. Retrieved from http://www.spiegel.de/international/world/donaldtrump-the-role-of-the-media-in-addressing-the-threat-a-1133520.html

$C B C$. (2017). Canadian woman denied entry to U.S. after Muslim prayers found on her phone. Retrieved from http://www.cbc.ca/radio/asithappens/as-ithappens-wednesday-edition-1.3972400/canadian-woman-denied-entry-to-us-after-muslim-prayers-found-on-her-phone-1.3972404

Chronicle of Higher Education. (2017). Here are 7 people whose lives were changed by the travel ban. Retrieved from http://www.chronicle.com/article/Here-Are-7-People-Whose-Lives/239053

Dunn, K., Pelleri, D., \& Maeder-Han, K. (2011). Attacks on Indian students: the commerce of denial in Australia. Race \& Class, 52(4), 71-88.

Ewers, M., \& Lewis, J. (2008). Risk and the securitisation of student migration to the United States. Tijdschrift voor Economische en Sociale Geografie, 99(4), 470-482.

Glass, C. (2017). Resilience for a world in flux. Journal of International Students, 7(2), I-III.

Graham-Harrison, E. (2017). US border agents ask Muhammad Ali's son: "Are you a Muslim?" The Guardian. Retrieved from https://www.theguardian.com/usnews/2017/feb/25/muhammad-ali-son-detained-questioned-us-border-control Institute of International Education. (2016). International Student Totals by Place of Origin, 2014/15- 2015/16. Open Doors Report on International Educational Exchange. Retrieved from http://www.iie.org/opendoors

Li, G. (2016). Politically sensitive Chinese students' engagement with democracy in Canada. Journal of Chinese Overseas, 12(1), 96-121.

Madge, C., Raghuram, P., \& Noxolo, P. (2009). Engaged pedagogy and responsibility: A postcolonial analysis of international students. Geoforum, 40(1), 34-45.

Morris, S. (2017). British Muslim teacher denied entry to US on school trip. The Guardian. Retrieved from https://www.theguardian.com/usnews/2017/feb/20/british-muslim-teacher-denied-entry-to-us-on-school-trip

Paltridge, T., Mayson, S., \& Schapper, J. (2014). Welcome and exclusion: an analysis of The Australian newspaper's coverage of international students. Higher Education, 68(1), 103-116.

Robertson, S. (2011). Cash cows, backdoor migrants, or activist citizens? International students, citizenship, and rights in Australia. Ethnic and Racial Studies, 34(12), 2192-2211.

Urias, D., \& Yeakey, C. (2009). Analysis of the U.S. student visa system. Journal of Studies in International Education, 13(1), 72-109.

Walker, P. (2014). International student policies in UK higher education from colonialism to the coalition: developments and consequences. Journal of Studies in International Education, 18(4), 325-344.

CINDYANN ROSE-REDWOOD, PhD, is an Assistant Teaching Professor in the Department of Geography at the University of Victoria. Her research examines the social experiences of international students in higher education settings, the social geographies of immigrant communities in North American cities, and the Caribbean 
diaspora. She is currently co-editing a book entitled, International Encounters: Higher Education and the International Student Experience (with Reuben RoseRedwood).

REUBEN ROSE-REDWOOD, $\mathrm{PhD}$, is an Associate Professor in the Department of Geography at the University of Victoria. His research examines the cultural politics of place, critical social theory, and the spatiality of power. He is the editor of Performativity, Politics, and the Production of Social Space (2014, with Michael Glass), The Political Life of Urban Streetscapes (2017, with Derek Alderman and Maoz Azaryahu), and is currently co-editing a book entitled, International Encounters: Higher Education and the International Student Experience (with CindyAnn Rose-Redwood). 